\title{
NOTES
}

\section{Historical Note on Chloropseudomonas ethylica Strain 2-K}

\author{
JOHN M. OLSON \\ Biology Department, Brookhaven National Laboratory, Upton, New York 11973
}

\begin{abstract}
The first published report of green photosynthetic bacteria isolated from mud samples from Kuyal'nik estuary and Lake Sakski by Shaposhnikov and co-workers in 1959 indicated that the organisms were nonmotile, rather than motile, short rods, as subsequently reported.
\end{abstract}

Gray et al. $(2,3)$ have presented convincing evidence that cultures of "Chloropseudomonas ethylica" strain $2-\mathrm{K}$ are in reality syntrophic mixtures of Chlorobium limicola (a nonmotile, green photosynthetic bacterium) and one or more motile, colorless, non-photosynthetic bacteria.

Cultures of "Chloropseudomonas ethylica" maintained at Brookhaven National Laboratory were obtained from single-colony isolates from a culture kindly provided by E. N. Kondrat'eva of Moscow State University in August 1961. The original organisms designated "strain 2-K" were obtained from mud samples from Kuyal nik estuary near Odessa by Shaposhnikov and co-workers $(4,5)$. In the first published report (5) of both strain 2-K (Kuyal'nik estuary) and strain 3-S (Lake Sakski), Shaposhnikov et al. described the organisms as "non-motile short bacilli" (nepodvizhnye Korotkie palochki) approximately $1 \mu \mathrm{m}$ in size and proposed the name Chlorobium ethylicum. In the second published report (4) Shaposhnikov et al. described the organisms as "motile, short, rod-shaped cells measuring about 1.0-1.5 $\times 0.8-0.9 \mu \mathrm{m}$ " and proposed the name Chloropseudomonas ethylicum. Subsequently Skalinskii and Kondrat'eva (6) pointed out the inconsistency between the first two reports $(4,5)$ and indicated clearly the absence of flagellated bacteria in cultures of Chlorobium thiosulfatophilum and the presence of flagellated bacteria in cultures of "Chloropseudomonas ethylicum."

Since Gray et al. $(2,3)$ have shown that all cultures of "Chloropseudomonas ethylica" strain 2-K obtained from several laboratories consist of mixed cultures of Chlorobium li- micola and at least one colorless motile bacterium, it is relevant that Pfennig and Trüper (7), on the basis of publications by and personal communication with Russian workers, described Chlorobium limicola and Chloropseudomonas ethylica as follows:

Chlorobium limicola: "Cells rodshaped .... Color of individual cells light green (italics added), color of cell suspensions green."

Chloropseudomonas ethylica: "Cells 0.7 to $0.9 \mu \mathrm{m}$ wide, 1.0 to $1.5 \mu \mathrm{m}$ long. Motile by means of one polar or subpolar flagellum. Individual cells colorless (italics added), color of cell suspensions green."

Based on the available evidence, it seems doubtful that the green photosynthetic bacteria isolated by Shaposhnikov and co-workers in 1959 included a true Chloropseudomonas as defined by Czurda and Maresch (1) and Pfennig and Trüper (8).

Work at Brookhaven National Laboratory was supported by the U.S. Atomic Energy Commission.

I thank Brian Gray, Fred Fowler, Noel Nugent, Nicolas Rigopoulos, and Clint Fuller for sending me copies of their papers $(2,3)$ prior to publication.

\section{LITERATURE CITED}

1. Czurda, V., and E. Maresch. 1937. Beitrag zur Kenntnis der Athiorhodobakterien-Gesellschaften. Arch. Mikrobiol. 8:99-124.

2. Gray, B. H., C. F. Fowler, N. A. Nugent, and R. C. Fuller. 1972. A reevaluation of the presence of low midpoint potential cytochrome 551.5 in the green photosynthetic bacterium Chloropseudomonas 
ethylica. Biochem. Biophys. Res. Commun. 47:322-327.

3. Gray, B. H., C. F. Fowler, N. A. Nugent, N. Rigopoulos, and R. C. Fuller. 1973. Reevaluation of Chloropseudomonas ethylica strain 2-K. Int. J. Syst. Bacteriol. 23:256-264.

4. Shaposhnikov, V. V., E. N. Kondratieva, and V. D. Fedorov. 1960. A new species of green sulphur bacteria. Nature (London) 187:167-168.

5. Shaposhnikov, V. N., E. N. Kondrat'eva, E. N. Krasil'nikova, and A. A. Ramenskaya. 1959. Green bacteria utilizing organic compounds. Dokl. Akad.
Nauk SSSR 129:1424-1426.

6. Skalinskii, E. 1., and E. N. Kondrat'eva. 1961. A new species of green sulfur bacteria. Dokl. Akad. Nauk SSSR 138:456-457.

7. Pfennig, N., and H. G. Trüper. 1969. Phototrophic bacteria. Gesellschaft für Strahlenforschung mbH., München.

8. Pfenning, N., and H. G. Trüper. 1969. Proposal to declare Rhodopseudomonas palustris and Chloropseudomonas ethylica as nomina conservanda. Int. J. Syst. Bacteriol. 19:153-154. 